\title{
Strategies for Answering TOEFL: The Correlation Study between Its Use and the EFL Students' Listening Score
}

\author{
Ika Hidayanti ${ }^{1 *}$, Alfan Zuhairi ${ }^{2}$, Kurniasih ${ }^{3}$ \\ ${ }^{1,2,3}$ Universitas Islam Malang. \\ *Corresponding author. Email: ikahidayanti@unisma.ac.id
}

\begin{abstract}
The EFL students need to take the TOEFL test to measure their English achievement, and this is also a compulsory test regulated by universities. This study was taken place in Universitas Islam Malang, especially English Department Students at Faculty of Education. The objectives are to investigate whether there is significant different on the strategy attainment between high and low achiever students and to know the interrelation between the strategy use and their listening score. Having been analyzed using T-test and correlation statistics, it reveals that successful students deployed the overall strategies at higher mean than their counterparts. However, the overall use of the strategy does not correlate to the listening score. Thus, the EFL students need to be more aware and select the suitable strategies when they are doing the TOEFL test.
\end{abstract}

Keywords: TOEFL strategies, Listening score, Successful and less successful EFL Learners.

\section{INTRODUCTION}

The test score for TOEFL is measured based on the result from three sections of listening comprehension, structure and written expression, and reading comprehension [11]. This test is conducted generally at most of universities to measure the student's English proficiency, and Universitas Islam Malang has labelled this as TOEFL prediction or Test of English Proficiency (TEP) and set out that the requirement scores range from 450 as a minimum score for non-English students and 500 for English students.

Among three sections, listening is counted as the difficult section taken by EFL students. Thus, they need to take some strategic ways as they are listening to more extended and various passages; moreover, they should be accustomed to listen both dialogues and monologues in TOEFL [12]. In the process of listening to monologues, the listener should "process long stretches of speech without interruption-the stream of speech will go on whether or not the hearer comprehends", and to identify the 'interpersonal and transactional' aspects from listening to dialogues [1]. Besides, listening to natives requires some strategic ways of comprehension that many of students would often find difficulties for some aspects; thus, the EFL teachers could facilitate and train students to cope with some learning materials, time management, media and the gradual teaching listening should be from "basic to more complex" [13]. Therefore, it is necessary to carefully arrange the listening activities with one progress to further complicated processes [2]. The successful teaching and learning could also be enhanced by the use of 'innovative strategies' [8].

Factually, there are less awareness on the use of strategies in listening. EFL students then need to highlight their focus on identifying the key ideas and 'nonverbal cues' and contextual clues to guess the meaning, making prediction and clarification based on the aural text [1]. Thus, the strategy training and development should be put in the teaching listening and joining the TOEFL test instead.

A lot studies have been taken to investigate the influence of the strategies choice and the listening score. 
Nurhayati and Nehe [9] purposed the research on identifying the difficult questions found in TOEFL and the students' scores. It was found out that comprehending the idioms in listening became the most complicated question faced by the students. Further, the result indicated that the overall score was low in the use of strategies for listening [4]. come with the findings that the strategy deployment did not correlate to the second-year students' English listening proficiency. Instead, the successful students compromised with some learning strategies to comprehend the listening texts.

Further study conducted by Hadi, Adnan, \& Wahyuni [3] investigated the strategy profile of EFL students at English department, State University of Padang and the difference strategy deployment by successful and less-successful students. The findings indicated that they used the learning strategies at high level, and the high achievers intensively implemented the metacognitive strategies. Moreover, Ismail \& Aziz [7] found that the English students of Faculty Education, Universiti Kebangsaan Malasyia attained bottom-up, top-down, and interactive processing in learning listening.

Today's pandemic situation creates the learning environment as in the form of online system. Consequently, the internal test center, Foreign Language Development Center (FLDC), facilitates and provides the online learning and test. Each student should be well- prepared for the online system and the test application. This system could lead to some technical and practical problems as well. Thus, focusing on the strategy choices could affect the result on test score.

\section{LITERATURE REVIEW}

The term listening ability refers to the students' capability to comprehend and obtain the key ideas and contextual meaning from the aural text (Cambridge Assessment English, 2020), specifically, this refers to get the intended score on the listening section in TOEFL test. The strategy framework specifically refers to Philip's Longman Introductory for TOEFL Test [11]. The strategy items were presented as follows:

Part A comprises into 3 items of:

- Gaining the focus on the second line or speaker in the short dialogues

- $\quad$ Finding the answers with synonyms and restatements.
- Avoiding the same word or similar sounds of the words.

Part B and C involves both pre- (items 4 \& 5) and whilst $(6,7,8, \& 9)$ listening activitiesbelow:

- Anticipating the topics by looking at the options of the answers

- Guessing the questions

- Getting focus on the first line on the aural text

- Determining the topics and the main idea

- Drawing conclusions about who, what, when, and where the conversation or talk happens

- Looking and following along the answers while listening to the recording

\section{METHOD}

The quantitative approach was implemented, focusing on the Independent T-test and correlation data analysis. The seventh semester students were enrolled, especially for those who took online TOEFL preparation/TEP held by Foreign Language Development Center (FLDC). After joining the test, the students were asked to fill out the questionnaire via Google Form.

The questionnaire with 9 items of strategies was derived from Longman TOEFL Introductory level by Longman [11] and comprises the strategies for part A, B, and C. The use of questionnaire was intended to answer the first problem, and the converted listening scores were also used to group the high and low achiever students. Utilizing the analysis of Independent T-test and correlation, the data were counted and to answer the research problems. Further to interpreting the correlation, the statistical result shows "large" if the $r=.50$ to 1.0 or $\mathrm{r}=.50$ to -1.0 , "medium" if the $\mathrm{r}=.30$ t0 .49 or $\mathrm{r}=.30$ to -.49 , and "small" if the r=.10 t0 .29 or $r=.10$ to $.29[10]$.

\section{FINDINGS AND DISCUSSION}

\subsection{Finding 1: The Difference Use of Strategies in Answering TEP by High and Low AchieverLearners}

The result on Table 1 reveals that the high achiever students attained higher mean for most of strategies. The highest mean lies on the use of strategy 9 which refers to gaining the answers for part $\mathrm{B}$ and $\mathrm{C}$ while listening to natives. In opposite, the successful students did not show different use of strategy to guess the topic, when and where about the conversation and talk 


\subsection{Finding 2: The Correlation between Strategy Deployment and the Listening Score}

The statistical analysis on correlation shows the significant value is $.317>.05$. This means that there is no significant correlation between the strategy choice and the students' listening scores for TOEFL. This implies the use of strategies did not affect the students
In terms of strategy choice by successful students, the finding supports the study by Hidayanti \& Umamah [5]; Hidayanti, Suhartoyo, \& Kurniasih [6] that doing the listening task could be done easily by maintaining the focus on the strategies. Nevertheless, the second finding was also in line that there is no interrelation between the strategy selection and the listening score. Talking further about the strategy selection, Nurhayati and Nehe [9] confirmed that

Table 1: The difference on the strategy attainment by high achiever (53) and low achiever (21) EFL students

\begin{tabular}{ll|c|c}
$\begin{array}{c}\text { Strategy } \\
\text { item }\end{array}$ & \multicolumn{1}{c|}{ Groups } & Mean (S.D) & $\begin{array}{c}\text { Mean } \\
\text { Difference }\end{array}$ \\
\hline Strategy 1 & High achiever & $2.74(.45)$ & .07 \\
& Low achiever & $2.67(.48)$ & .10 \\
\hline Strategy 2 & High achiever & $2.53(.54)$ & .07 \\
& Low achiever & $2.43(.51)$ & .14 \\
\hline Strategy 3 & High achiever & $2.55(.50)$ & .0 \\
& Low achiever & $2.48(.51)$ & .01 \\
\hline Strategy 4 & High achiever & $2.57(.50)$ & \\
& Low achiever & $2.43(.51)$ & .07 \\
\hline Strategy 5 & High achiever & $2.43(.51)$ & \\
& Low achiever & $2.11(.38)$ & -.1 \\
\hline Strategy 6 & High achiever & $2.10(.30)$ & .23 \\
& Low achiever & $2.26(.45)$ & \\
\hline Strategy 7 & High achiever & $2.19(.51)$ & \\
& Low achiever & $2.28(.46)$ & \\
\hline Strategy 8 & High achiever & $2.38(.50)$ & \\
& Low achiever & $2.75(.43)$ & \\
\hline Strategy 9 & High achiever & $2.52(.60)$ & \\
& Low achiever &
\end{tabular}

listening scorein TOEFL test.

The findings clearly stated that the two groups of students deployed the strategies differently. High achievers tend to use the strategies while they are answering the TOEFL test. In comparison with their counterparts, the more proficient learners accounted higher mean on the strategy item number 9 which refers to looking at the options of answers while they were listening to part $\mathrm{B}$ and $\mathrm{C}$ and followed by anticipating the topics before listening. In addition, they chose the key words and their synonyms to guess the contextual meaning in listening to short dialogues. In opposite, the two groups did not show significant difference when they encountered to anticipate and guess the questions in pre-listening activities. idiomatic expressions were the most difficult questions in the listening section. In relation to the current study, it reveals that the students thought part A was the difficult section so that they rarely used and focused on the strategies. However, the treatments for training the students to focus on the strategies could be beneficial to improve the students final test in TOEFL [4].

In terms of insignificant correlation, there are possible reasons that affect the listening score. First, the online system leads the problem on getting good signal because of their area or weather. Then the students encountered limited time as they need to finish the task within 35 minutes. As they are not accustomed to listening to English natives, they felt lack of time to comprehend the aural texts. Besides, some students might play the audio repeatedly so that they could not 
finish all the questions. Another reason is that about $50 \%$ of the students filled out the questionnaire a day after the test time that it should be done directly after joining the test.

\section{CONCLUSION}

In short, the use of strategies in answering TOEFL test selected differently by the two groups could successfully affect the more proficient learners' listening scores than their counterparts. The overall use of strategies did not correlate significantly to the students' scores for some possible reasons presented in the previous section. For pedagogical implications, TOEFL lecturers should train more on the strategy deployment when doing the test. In addition, being strict to time management and playing the audio for once should be also emphasized when the students have their control toward the audio.

\section{REFERENCES}

[1] H. D. Brown, Teaching by Principles: An Interactive Approach to Language Pedagogy, Pearson Education, Cambridge Assessment English, Cambridge University Press, 2020.

[2] A. P. Gilakjani, M. R. Ahmadi, A Study of Factors Affecting EFL Learners' English Listening Comprehension and the Strategies for Improvement, in: Proceedings of Journal of Language Teaching and Research, vol.2, 2011, pp 977-988.

[3] M. S. Hadi, A. Adna, D. Wahyuni, The Analysis of Listening Strategies Used by the English Department Students of Faculty of Languages and Arts of Universitas Negeri Padang, inL Proceedings of Journal of English Language Teaching, vol. 5, 2016, pp. 201-210.

[4] S. Herwandar, D. A. Safryono, P. Y. Haryono, Evaluasi Program Matrikulasi "TOEFL" Mahasiswa Universitas Al Azhar Indonesia 2010/2011, in: Proceedings of Jurnal Al-Azhar Indonesia Seri Humaniora, Vol . 1, 2012.

[5] I. Hidayanti, A. Umamah, Listening Strategy: A Link between Gender and Student's Achievement, in: Proceedings of Abjadia, vol. 4, 2019, pp. 12-17.

[6] I. Hidayanti, E. Suhartoyo, K. Kurniasih, Utilizing Strategy-Based Instruction on the EFL Listening Achievement: A Quasi-Experimental Study, in: Proceedings of JEELS, vol. 7, 2020. JEELS, pp. 371-386.

[7] N. S. C. Ismail, A.A. Aziz, The Teaching of Listening Strategies in ESL Classroom, in: Proceedings of International Journal of Academic
Research in Business and Social Sciences, vol. 10, 2020, pp. 197-209.

[8] I. U. Khan, Strategies for Improving English Language Listening Skill (The Case of Distract BANNU), in: Proceedings of Research on Humanities and Social Sciences, vol. 4, 2014, pp. 37-49.

[9] N. Nurhayati, B. M. Nehe, An Analysis of Students' Strategies in Answering TOEFL, in: Proceedings of The Journal of English Language Studies, vol. 1, 2016, pp. 10-18.

[10] J. F. Pallant, SPSS Survival Manual: A Step-by-step Guide to Data Analysis Using SPSS, Crows Nest, NSW, Allen \& Unwin. 2011.

[11] P. D. Longman, Introductory Course for the TOEFL Test, Pearson Education, 2004.

[12] T. M. Silviyanti, R. Rahmadhani, I. A. Samad, EFL Students' Strategies in Answering the Listening Section of the Longman TOEFL, in: Proceedings of Studies in English Language and Education, vol. 7, 2020, pp. 237-246.

[13] D. R. Saraswaty, Learners' Difficulties \& Strategies in Listening Comprehension, in: Proceedings of English Community Journal, vol. 2, 2018, pp. 139-152. 